\title{
ISSUES REGARDING MANAGEMENT OF MACHINING TOOLS, PARTS AND SUB- ASSEMBLIES IN FLEXIBLE MANUFACTURING CELLS
}

\author{
FL. AVRAM \\ Department of Mechatronics, Faculty of Managerial and \\ Technological Engineering, University of Oradea \\ favram@uoradea.ro \\ AR. NILGESZ \\ Department of Mechatronics, Faculty of Managerial and \\ Technological Engineering, University of Oradea \\ arnoldnilgesz@gmail.com
}

\begin{abstract}
This paper will be presenting the issues regarding management of machining tools, parts and sub-assemblies in the industrial environment present in flexible manufacturing cells, flexible manufacturing systems or flexible manufacturing multisystems. In modern the factory environment, management plays vital role in assuring a quality on demand, cost effective and timely production planning. Without proper management performance is not guaranteed or controlled in a manufacturing cell system.
\end{abstract}

Keywords - Manufacture, Management, Machining Tools, Subassemblies, Flexible Manufacturing Cells

\section{INTRODUCTION}

As shown in [1], a flexible cell contains several production equipment connected to one another. A flexible manufacturing system (FMS) is an integrated group of industrial equipment such as $\mathrm{CNC}$ machining and computerized material handling equipment for automatic processing of palletized parts. These types of systems are implemented for medium production and represents a compromise between the hight flexibility of flexible jobs and the high production rate of a dedicated mass production system (eg transfer lines). It is able to produce a limited number of pre-planned parts of families and uses similarities between members of a family of parties using group technology [2].

The advantages of implementing of flexible manufacturing systems are presented in [3].and they are:

- universality: dimensioning, different product designing or technology requirements, eg flexibility in typology of variants.

- mobility: unrestricted mobility of objects, for example, wheeled machines.

- scalability: technical, spatial, as well as extensibility or reduction of staff, eg flexibility of working time.

- modularity: standardized units or elements.

Just as in other areas in the case of manufacturing cells, proper management is needed for good performance. Both in terms of investments in equipment and how to deploy new implementations, as specified in [4], and in terms of energy, aspect presented in [5].

The aspect of reducing implementation costs are taken into consideration from the start, from layout design to designing an

\author{
FL. BIROUAS \\ Department of Mechatronics, Faculty of Managerial and \\ Technological Engineering, University of Oradea \\ fbirouas@uoradea.ro \\ VL. MIHALCA \\ Department of Mechatronics, Faculty of Managerial and \\ Technological Engineering, University of Oradea \\ ovidiu@vmihalca.ro
}

optimal configuration of the machine for each stage of the process [6].

\section{RECONFIGURATION OF A FLEXIBLE MANUFACTURING SYSTEMS OR CELLS, EVOLUTION OVER TIME.}

Industrial systems have experienced a double evolution over the last decade: Firstly, there is a deeper integration of all participants in the industrial system, from raw material suppliers to the customer service department that caters to growing customer demands. This is conceptually known as a 'supply chain', generally internationally, as the market is globalized. The second evolution is due to an increasing need for flexibility and reactivity, on the one hand, to respond to an increasing demand and, on the other hand, to have a better response to breaks in production systems. The structure of the manufacturing systems is impacted by these new developments [7].

The manufacturing systems and cells have evolved over time, from the manual work system to a high productivity machines with artificial intelligence system, the role of human operator and automation is illustrated in Figure 2.1. [5].

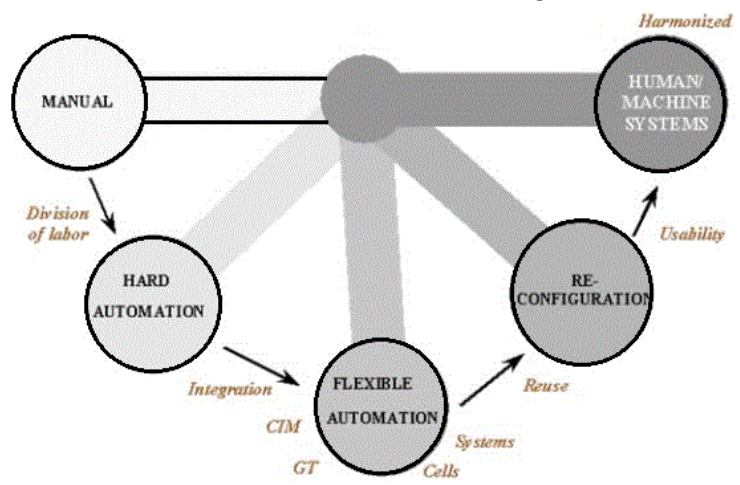

Fig. 2.1.The role of human interaction in the evolution of manufacturing systems

[5.]

Flexible Manufacturing Cells (FMC) all connected via an automatic material handling system make up a flexible multicell manufacturing system (MCFMS), all of which are connected by an automatic material handling system. Such MCFMS focuses on reducing the proportion of time spent on 
non-productive activities such as material handling and waiting in relation to actual processing time. Along with these there are reconfigurable work systems.

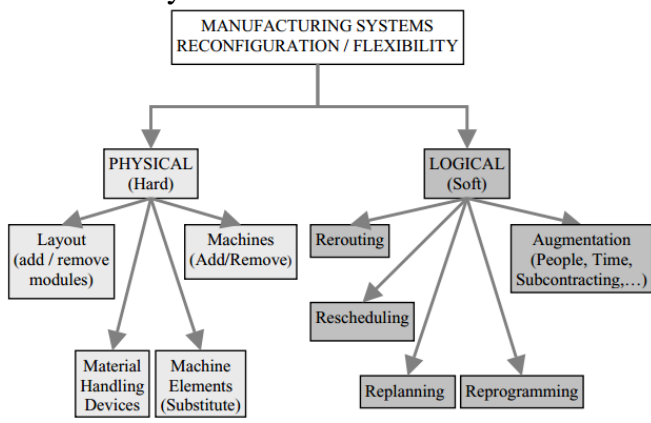

Fig. 2.2 Manufacturing systems reconfiguration [5]

The reconfigurable manufacturing system (RMS) is a new paradigm of manufacturing systems that seeks cost-effective industrial solutions for a market that demands a rapid iteration of products in design. A system is Cost-effective when it incorporates the principles of modularity, integrity, flexibility, scalability, convertibility and diagnosis. [1].

In Figure 2.2. can be observed a diagram regarding flexible reconfigurable manufacturing system [5]

\section{III.MODELING OF FLEXIBLEMANUFACTURING CELL AND SYSTEMS}

As in other industrial areas, and in the case of flexible cell and manufacturing systems, modelling is needed. In the paper [8] is presented a variant of modelling a robotic fabrication cell on several hierarchical levels, figure 3.1., in order to notice some timely changes to lower levels:

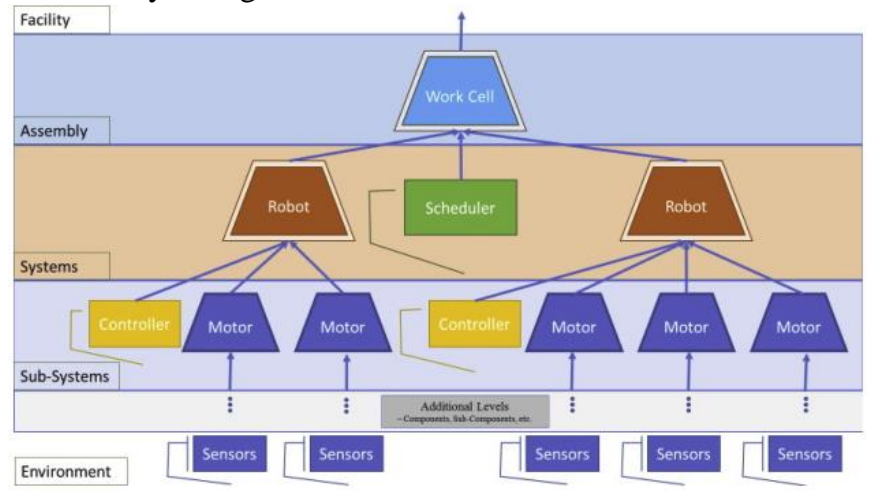

Fig. 3.1.Modeling a robotic manufacturing cell on several hierarchical levels [8].

In figure 3.2. this model is exemplified. Each node or submodel is an autonomous "local evaluator" that only processes data from relevant level subsystems. For this reason, both construction and conversion can be done in a modular fashion. Although the primary function of each sub-model node is to consolidate and provide information from the level below to the above level, their results could be easily questioned by algorithms or users at any level of the hierarchy to help more detailed investigations of anomalies.

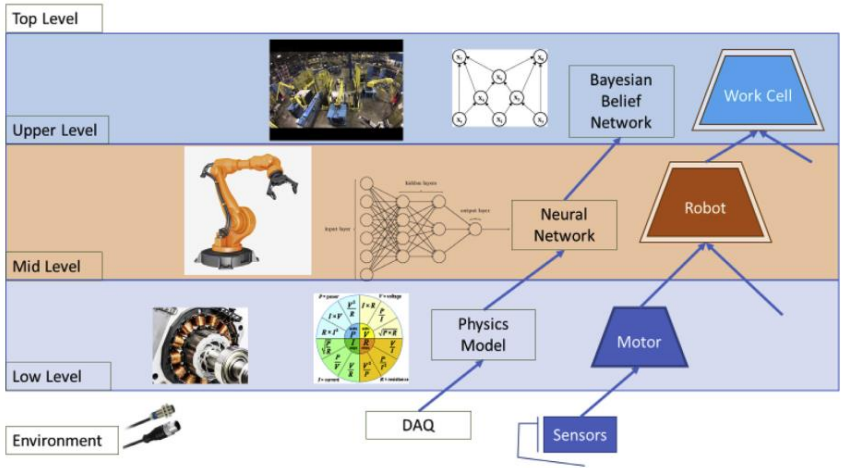

Fig. 3.2.Example of modelling a robotic manufacturing cell on several hierarchical levels [8].

\section{IV.PLANNING IN FLEXIBLE CELLS AND MANUFACTURING SYSTEMS}

In the manufacturing sector, such as the automotive industry, there is a difficulty in optimizing the use of their production resources, such as staff or existing resources. Nonuse of working capacity means financial loss and therefore less profit [9]. To avoid this, production planners always try to adapt processes, strategies, concepts and technical systems so they can control current uncertainties.

\section{A. Programming tools and work pieces in flexible cells}

The problem of loading a flexible cell or manufacturing system is considered to be a complex problem, finding a solution through conventional techniques requires much effort and time [10]. In [11] a simultaneous loading and programming of parts and tools is proposed for a flexible manufacturing system with identical work machines and a common tool magazine. All tools are stored in the common tool magazine and are divided between different machines through a material handling system. Each type of instrument is a unique number. For this, a modified genetic algorithm is used, as shown in [12].

In [13] there is a problem with finding a machine allocation, a corresponding sequence for the parts assigned to each machine, and an appropriate tool switching plan for each machine, so as to reduce the size of the workspace. Three heuristic procedures are proposed to solve this problem.

Another option to control and manage a repository associated with a flexible system or flexible manufacturing hose is presented in [14] which presents flexible production systems as complex, stochastic environments that require the development of innovative intelligent control architectures. The manufacturing cell control systems are now mostly affected by the lack of flexibility. Radio Frequency Identification (RFID) is implemented to overcome this inconvenience. It is a new technology that uses radio frequency waves to transfer data between a reader and a mobile element to identify, track and classify the goal.

Although planning-oriented approaches are supported by a multitude of systems in industrial practice, an effective achievement is very complicated, so that these models with their inherent structures tend to be matched by a company's current stationary state. Any change within this enterprise, whether inherently structured or driven by modified input parameters, requires an update and a continuous adjustment. This process is cost-intensive and consumes long; a direct transfer to other enterprises or even other processes within the same enterprise is often impossible. This is also the result of planning being usually a priori and not in real time. Therefore, fully-scheduling systems are hard to react to spontaneous 
deviations, as knowledge of them naturally occurs only a posterior [15].

\section{B. Managing the storage of a flexible manufacturing cell}

Within a flexible manufacturing cell, management is vital, and without this management one cannot reach a cell or manufacturing system with high performance. The management of a manufacturing cell must start from the central store where the work piece or tools feed is made. A storage element or devices is sometimes referred as magazine.

Next, we will analyze the case of a Regal store, starting from the simplest case. In Figure 4.1.the principle of this warehouse is presented, according to [16]:

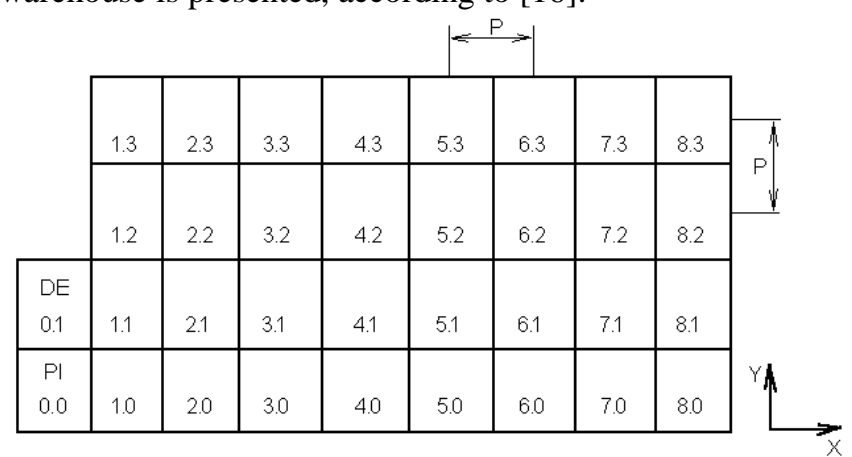

Fig. 4.1.The principle of the Regal magazine [16].

The Regal Magazine has a vertical matrix structure, usually with 2 rows of shelves and a lane in the middle, through which the robo-stacker or a manipulator moves in coordinates, accessing both sides of vertical racks. In order to be able to manage the store, it is necessary to encode the articles. In figure 4.2. Table 1 shows the single fixed management of a Regal store:

TABLE 1. REGAL MAGAZINE MANAGEMENT, AS A TABLE OF ARTICLE CODE ALLOCATIONS [16].

\begin{tabular}{|c|c|c|c|c|c|c|c|}
\hline 25 & 26 & 27 & 28 & 29 & 30 & 31 & 32 \\
\hline A0225 & $\mathrm{A} 0226$ & $\mathrm{~A} 0227$ & $\mathrm{~A} 0228$ & $\mathrm{~A} 0229$ & $\mathrm{~A} 0230$ & $\mathrm{~A} 0231$ & A0232 \\
\hline 17 & 18 & 19 & 20 & 21 & 22 & 23 & 24 \\
\hline $\mathrm{A} 0217$ & $\mathrm{~A} 0218$ & $\mathrm{~A} 0219$ & $\mathrm{~A} 0220$ & $\mathrm{~A} 0221$ & $\mathrm{~A} 0222$ & $\mathrm{~A} 0223$ & $\mathrm{~A} 0224$ \\
\hline 09 & 10 & 11 & 12 & 13 & 14 & 15 & 16 \\
\hline A0209 & $\mathrm{A} 0210$ & A0211 & $\mathrm{A} 0212$ & $\mathrm{~A} 0213$ & A0214 & $\mathrm{A} 0215$ & $\mathrm{~A} 0216$ \\
\hline 01 & 02 & 03 & 04 & 05 & 06 & 07 & 08 \\
\hline $\mathrm{A} 0201$ & $\mathrm{~A} 0202$ & $\mathrm{~A} 0203$ & A0204 & A0205 & A0206 & $\mathrm{A} 0207$ & A0208 \\
\hline
\end{tabular}

Singular Fixed Management is the procedure by which each hatch is allocated an item maximum (one or none in a fixed biweekly relation), the item may be out of management but returns to its original location. The 32 locations in the example in the figure are assigned 32 RAM addresses, with the above-mentioned codes, where the code of the articles in the management is stored. On the computer screen, the code assignment map and the content list of managed items appear. At each recess, the $\mathrm{X}$ and $\mathrm{Y}$ coordinates of the Regal hold are also assigned, so the robot is given these coordinates to which they must move. Barr readers are required to check these codes (both when picking up and depositing).

\section{MANAGING THE MANIPULATOR OR ROBOT SERVING THE REGAL STORAGE}

If the magazine is served by a loading robot, a shortest path algorithm must be implemented. In figure 5.1 one such algorithm is presented:

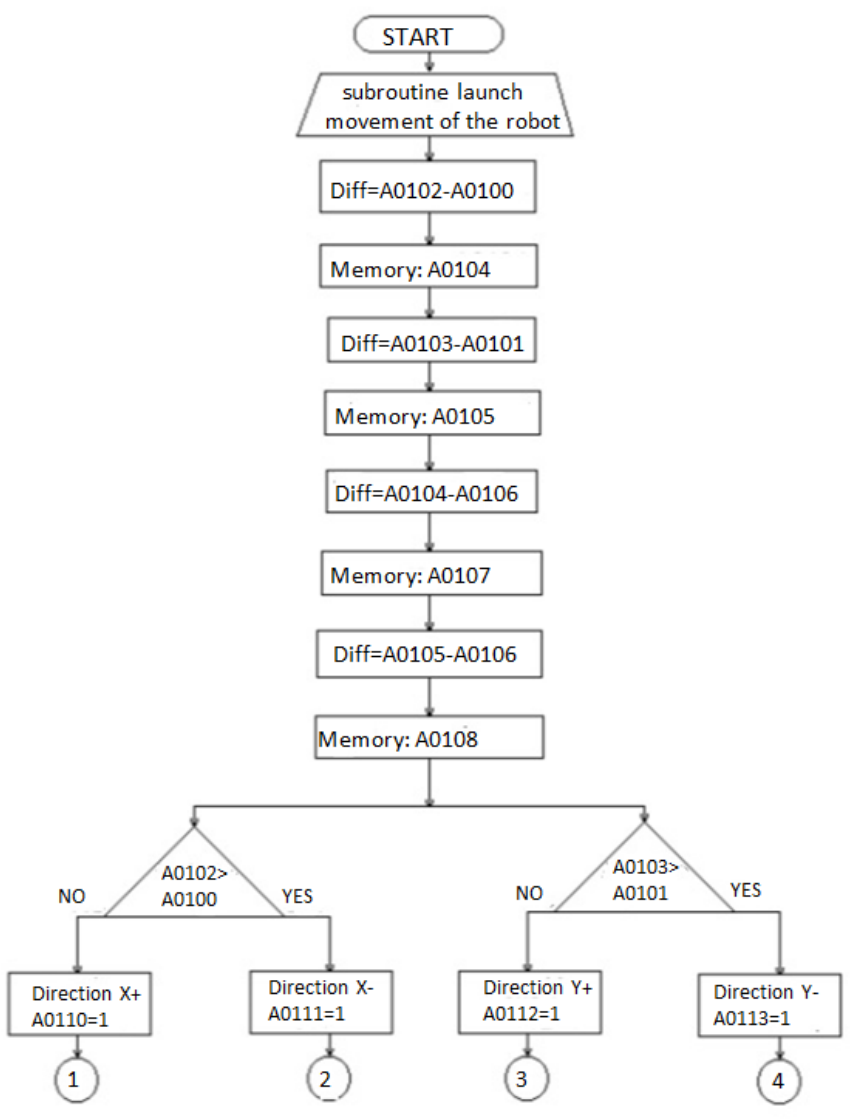

Fig. 5.1. Search algorithm for the shortest route for the Regal magazine [16].

$\mathrm{XN}, \mathrm{YN}=$ the coordinates of the cell to which the robot is intended to move

$\mathrm{A} 0100=$ contains the " $\mathrm{X}$ " coordinate of the target cell

A0101 = contains the "Y" coordinate of the target cell

$\mathrm{A} 0102$ = contains the coordinate " $\mathrm{X}$ " of the current cell (where the robot is located)

A0103 = contains the "Y" coordinate of the current cell

A0104 = contains the "distance" on the "X" between the target cell and the current cell

A0105 = contains the "distance" on the "Y" between the target cell and the current cell

A0106 $=$ Contains the number of pulses corresponding to the low speed travel area

A0107 = Contains the number of pulses corresponding to the horizontal displacement " $\mathrm{X}$ " at a fast speed

A0108 = Contains the number of impulses corresponding to the vertical displacement "Y" with fast speed.

In figure 5.2 is presented the flexible manufacturing cell assembly at the University of Oradea, 3D model, including Regal store:

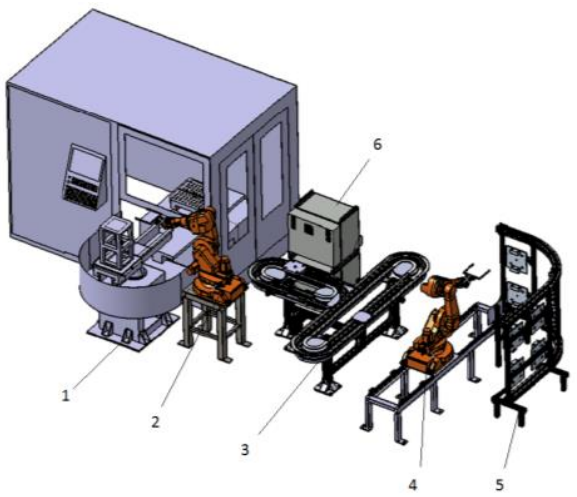

Fig. 5.2.The layout for flexible manufacturing cell. 
The flexible manufacturing cell UO-01-FMC, presented in Figure 5.2 of the University of Oradea, consists of a processing centre TMA-AL-550 (1), a modular belt conveyor (3), two industrial robots ABB- IRB-1600-6 / 1.2 with six RRRRR axes, one of which is a fixed one on the stand (2) and one with an additional translation axis (4), a central Regal magazine (5) and the robot controller (6).

The case of the Regal magazine held by the robo-stacker manipulator is much simpler than the case when the stowage is robot-free. This is because the fixed cycles are repeatable at each magazine cell, the driving cycles contain the sequences on the two axles of the manipulator, the confirmations are by racing limiters. Because of this, it is necessary to assemble a complete manufacturing cycle for the desired central computer target, containing the palette code with the blank to be processed, the coordinates of the picking and depositing points in and for the robot or manipulator magazine and the pallet code containing the tool required for machining on the work machine.

The control of pallets containing parts or semimanufactured or tools is made with Radio Frequency Identification (RFID).

\section{VI.CONCLUSIONS}

In order for a cell or a flexible manufacturing system to function at the flexibility and performance requirements, it is imperative to have a correct and concrete management of the central or temporary warehouse for semi-finished products, finished parts or work tools.

This management can be accomplished using several of the above mentioned processes: modified genetic algorithm, heuristic procedures, or Radio Frequency Identification (RFID) control.

\section{Acknowledgment}

$\mathrm{PhD}$ School of Engineering Sciences - University of Oradea

\section{References}

1. (2000) MULTICELL FLEXIBLE MANUFACTURING SYSTEM. In: Swamidass P.M. (eds) Encyclopedia of Production and Manufacturing Management. Springer, Boston, MA.

2. ElMaraghy H., Caggiano A. (2014) Flexible Manufacturing System. In: The International Academy for Production Engineering, Laperrière L., Reinhart G. (eds) CIRP Encyclopedia of Production Engineering. Springer, Berlin, Heidelberg

3. ElMaraghy, H.A. Int J Flex Manuf Syst (2005) 17: 261. https://doi.org/10.1007/s10696-006-9028-7

4. Smith G.T. (1993) Current Developments in Flexible Manufacturing Cells and Systems, Leading to Complete Computer Integrated Manufacture. In: CNC Machining Technology. Springer, London.

5. Energy management in manufacturing: From literature review to a conceptual framework

Gökan May, Bojan Stahl, MarcoTaisch, Dimitris Kiritsis, 2016, Elsevier

6. Moslemipour, G. \& Lee, T.S. J Intell Manuf (2012) 23: 1849. https://doi.org/10.1007/s10845-010-0499-8.

7. Quintanilla F.G., Cardin O., Castagna P. (2013) Evolution of a Flexible Manufacturing System: From Communicating to Autonomous Product. In: Borangiu T., Thomas A., Trentesaux D. (eds) Service Orientation in Holonic and Multi Agent Manufacturing and Robotics. Studies in Computational Intelligence, vol 472. Springer, Berlin, Heidelberg

8. Michael Sharp, Brian A. Weiss, Hierarchical modeling of a manufacturing work cell to promote

contextualized PHM information across multiple levels,

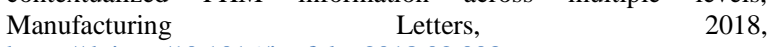
https://doi.org/10.1016/j.mfglet.2018.02.003
9. Klempke T, Mersmann T, Nyhuis P. Wandlungsfähige Produktionssysteme. Methodik zur Bewertung und Gestaltung der Wandlungsfähigkeit. In: wt Werkstattstechnik online, Jg. 102, Heft 4, 2012, S.222

10. Krappe H, Rogalski S, Sander M. Challenges for Handling Flexibility in the Change Management Process of Manufacturing Systems. Shanghai: IEEE Conference on Automation Science and Engineering (IEEE-CASE), 2006, S.551.

11. Godinho Filho, M., Barco, C.F. \& Tavares Neto, R.F. Flex Serv Manuf J (2014) 26: 408. https://doi.org/10.1007/s10696-0129143-6.

12. Moacir Godinho Filho, Clarissa Fullin Barco, Roberto Fernandes Tavares Neto, Using Genetic Algorithms to solve scheduling problems on flexible manufacturing systems (FMS): a literature survey, classification and analysis, 2012, SpringerLink.

13. Y. Fathi, K. W. Barnette, Heuristic procedures for the parallel machine problem with tool switches, 2010, https://doi.org/10.1080/00207540110076115.

14. Reza Vatankhah Barenji, Ali Vatankhah Barenji, Majid Hashemipour, A multi-agent RFID-enabled distributed control system for a flexible manufacturing shop, 2014, SpringerLink.

15. Schmitt R. et al. (2012) Self-optimising Production Systems. In: Brecher C. (eds) Integrative Production Technology for HighWage Countries. Springer, Berlin, Heidelberg.

16. Ganea, Macedon, Machine tools and flexible systems, University of Oradea, 2010 